\title{
A MAGYAR VILLAMOSENERGIA PIAC ALAKULÁSA NAPJAINKBAN
}

\author{
Csipkés Margit
}

\begin{abstract}
Absztrakt: Jelenleg Magyarországon a villamosenergia piacot érdemes vizsgálni, mivel az elmúlt év adatait áttekintve változások következtek be. Jelenleg a magyar villamosenergia piacot a HUPX ZRt. müködteti, mely a közép-kelet-európai régióban elég magasan szinten elismert.

A HUPX ZRt. célja a szervezett villamosenergia-piac magyarországi müködtetése a magyar villamos energia törvény és a Magyar Energia Hivatal által kiadott engedélyek rendelkezései alapján. A müködtetésénél fő cél a legkorszerübb villamosenergia-kereskedési platformjainak az alkalmazása, amelyek keretében villamosenergia-kereskedelem és egyéb kapcsolódó ügyletek kerülhetnek lebonyolításra szabványosított szerződések formájában. A vállalkozás egy innovatívan müködő szervezet, mely a szabályozottságával elősegíti a magyarországi energiapiac likviditásának erősítését, illetve a hatékonyságának a növekedését. A vállalkozás fő célja, hogy a referenciaár, illetve a tőzsdei kereskedési felület müködtetésével hozzájáruljon a szabad piaci kereskedelemhez, valamint a magyarországi villamosenergia-piac fejlődéséhez. A magyarországi villamosenergia kereskedelem akkor tud a jövőben fejlődni, ha az ,áramtőzsde” nagyobb mértékben kerül kihasználásra.

Cikkemben a „HUPX” piac gazdasági jelentőségét kívánom vizsgálni Magyarországon hosszú idősorokon keresztül. Fontosnak tartom bemutatni az úgynevezett „,másnapi piacot”, illetve a „,napon belüli piacot" is, melyek a szabad kereskedelem egyik kilépési lehetőségét adhatja Magyarországnak a jövőben.
\end{abstract}

Számításaimban a MAVIR ZRt. (a magyarországi Átviteli Rendszerirányító) által irányított magyar közcélú hálózaton leszállított villamos energiát vizsgálom. Természetesen a villamosenergia piac vizsgálatánál figyelembe veszem a magyar villamosenergia-rendszer Üzemi Szabályzatának rendelkezéseit is.

Abstract: Currently, it is worth examining the electricity market in Hungary, as there have been changes in the data of the past year. Righ now, the Hungarian electricity market is operated by HUPX ZRt., which is highly recognized in the Central and Eastern European region.

The aim of HUPX Ltd. is to operate the organized electricity market in Hungary on the basis of the provisions of the Hungarian Electricity Act and the permits issued by the Hungarian Energy Office. The main purpose of its operation is to use the most modern electricity trading platforms, where electricity trading and other related transactions can be executed in the form of standardized contracts. The enterprise is an innovative organization that, through its regulation, promotes the strengthening of the liquidity of the Hungarian energy market and the increase of its efficiency. The main goal of the company is to contribute to free market trading and the development of the Hungarian electricity market by operating the reference price and the trading market. The electricity trade in Hungary can develop in the future if the power exchange is exploited to a greater extent.

In my article I would like to examine the economic importance of the HUPX market in Hungary through long time series. I also consider it important to present the so-called "day-ahead market" and the "day-to-day market", which may give Hungary an opportunity to exit free trade in the future.

In my calculations I examine the electricity supplied by the Hungarian public utility network controlled by MAVIR ZRt. (Transmission System Operator in Hungary). Of course, in the examination of the electricity market, I also take into account the provisions of the Operational Rules of the Hungarian Electricity System.

Kulcsszavak: villamos energia, tőzsde, kereskedelem, HUPX, MAVIR, megújuló energiaforrások

Keywords: electricity, stock exchange, commerce, HUPX, MAVIR, renewable energy sources 


\section{Bevezetés - A magyar villamosenergia piac müködtetőjéről röviden}

2010. júliusában a MAVIR ZRt. leányvállalataként kezdte meg a munkáját a HUPX Magyar Szervezett Villamosenergia-piac Zártkörüen Müködő Részvénytársaság (továbbiakban HUPX ZRt.), amely a közép-kelet-európai régióban kiemelkedő szerepet tölt be, hozzájárul a teljes magyarországi gazdasági termelés hatékonyságához, valamint a villamos energia fogyasztói árának a mérsékléséhez (MAVIR, 2019). A cég fejlődésének köszönhetően a magyar villamosenergia-piac müködtetőjének számít jelenleg is, mivel a magyarországi energiapiac likviditásának erősítését segíti elö, valamint a hatékonyságának a növelését tüzte ki célul a jövőben (átlátható piac, biztonságos kereskedés, magyarországi villamosenergia piac fejlesztése, stb.).

A magyarországi villamosenergia piacon fontos szerepe van a HUPX-nak, mivel diszkriminációmentes kereskedést próbál kialakítani, egyenlő bánásmódot biztosít minden részvevő számára, egységes hozzáférés van mindenféle információhoz, a kereskedésben biztosítja az anonimitást, valamint kompatibilisnek tekinthető más tőzsdékkel szemben (HUPX, 2019a). A cég a kereskedési hálózatának a kiépítésével a határok menti piac összekapcsolását próbálja megvalósítani. A vevő és az eladó közötti kereskedésben biztosítja a fizetési kockázat nélküli kereskedést, az alacsony tranzakciós díjakat, a könnyített adminisztrációt, illetve a piaci átláthatóságot.

A vállalat számára fontos a referenciaár, valamint a tőzsdei kereskedési felület megfelelő biztosítása (céljuk, hogy döntő többségben az áramtőzsdén történjen meg a villamosenergia szabad kereskedelme), mely a magyar villamosenergia-piac fejlődéséhez szükséges. Az áramtőzsdén való szabályszerü megjelenéshez szükséges a jogszabályok pontos betartása, a résztvevő felek számára a letisztázott információk (rendelkezésre álló mennyiségek, felmerülő költségek, referencia árak ismerete, lebonyolítás menete, stb.) ismerete (HUPX, 2019b).

A HUPX (tagja lehet a Villamosenergia Kereskedő, az Egyetemes Szolgáltató, a felhasználó, a termelő, az Átviteli Rendszerirányító) a tiszta versenyhelyzetek, a jobb értékesíthetőség, illetve a határ menti országok közötti kereskedelmi kapcsolatok kialakítása érdekében létrehozott különböző piaci formákat. Ezek közül a legfontosabb a „Másnapi piac” és a „Napon belüli piac”.

A HUPX „Másnapi piac” elnevezésére a „HUPX DAM (Day-ahead market) kifejezést alkalmazzák. A kereskedés 2010. július 20-án indult meg legelöször. Ezen a piacon standard órás alapú és blokk másnapi szállítású villamos energia termékek kereskedése történik.

A HUPX másnapi piaca része az úgynevezett 4M MC piac összekapcsolásnak. Ezen összekapcsolódásba Csehország, Szlovákia, Magyarország és Románia vesz részt. A kapcsolatban a nemzeti szabályozó hatóságok, az átviteli rendszerirányítók és a szervezett villamosenergia-piaci szereplői vesznek részt. 2014. november 19-én hozták létre a cseh-szlovák-magyar másnapi villamosenergia-piac Romániával történő kiterjesztését, mely projektet 4M MC jelöléssel látták el. A 4M MC egy másnapi implicit allokációs eljárás, amely arra törekszik, hogy az EU célmodellel a lehető legnagyobb kompatibilitása legyen (HUPX, 2019a). 
A magyar villamosenergia-piac továbbfejlődése érdekében nélkülözhetetlen volt, hogy a szabadpiaci kereskedelem és a szállítás egymáshoz a lehető legközelebbi időpontban történjen, ezért is hozták létre a „Napon belüli Piacot (Intraday Market ID; HUPX ID). Célja ezen piacnak, hogy egy megbízható, modern szolgáltatást tudjanak a jövő generációjának kialakítani. Ez a piac 2016. március 9-én kezdte meg múködését, és a 2019. év első félévére tehető a továbbfejlesztett változata.

\section{Anyag és módszer}

A cikkemben szereplő számítások egy része a leíró statisztikai mutatók témakörébe tartozik. A számításoknál alkalmaztam az átlag, a szórás, az átlagbecslés, illetve a mértani átlag módszereket.

Az átlagok közül az egyszerü és súlyozott számtani átlagokat kalkuláltam, mely a számítások egy részének az alapját jelentette. A súlyozó tényező kiválasztása, minden esetben nagy odafigyelést igényelt.

A szórás alkalmazása azért volt fontos, mivel ezzel megtudtam, hogy az alapadatok a kalkulált átlag értékétől mennyivel térnek el átlagosan. Ez alapján határoztam meg a sokaság összetételét is.

$\mathrm{Az}$ átlagbecslés esetében minta átlagot, minta szórást, standard hibát $\left(\frac{s}{\sqrt{n}}\right), \mathrm{t}$ értéket, deltát $\left(t * S_{\bar{x}}\right.$ ) és konfidencia intervallumot számoltam $([\bar{x}-\Delta ; \bar{x}+\Delta])$. Ezzel meg tudtam határozni azt, hogy 5\%-os hibát feltételezve milyen értékösszegben mozogtak az értékesítési árak.

A mértani átlagot is alkalmaztam a kalkulációmban, mivel szükségem volt arra, hogy a vizsgált időszak első időpontjától a vizsgált időszak utolsó időpontjáig milyen tendencia mutatkozott meg. Itt növekvő és csökkenő tendenciák megállapítása mellett lehetőségem volt az átlagos változás mértékének a meghatározására is. Ebben az esetben dinamikus viszonyszámokat kellett először kalkulálni, majd ez után következett az átlag meghatározása. A cikkemben idősoros elemzést is készítettem, ahol szezonális eltérést kalkuláltam. Szakirodalmi áttekintés alapján az idősor azt jelenti, hogy valamely statisztikai jelenséget egy időbeli ismérv szerint rendezzük, és ezáltal vizsgáljuk a statisztikai jelenség időbeli változását. Abban az esetben, ha állapot idősor áll a rendelkezésünkre, akkor valamely álló sokaság időbeli változását mutathatjuk ki. Abban az esetben, ha tartam idősorunk van, akkor a mozgósokaságok időbeli változását mutathatjuk be. Mivel egy idősor nem lehet egyszerre álló és mozgó sokaság is, ezért a kétfajta idősor elemzési eszközei is eltérőek (az állósokaság egységeit csak akkor tudjuk időben elemezni, ha az idő egységei adott időpontok; a mozgó sokaság egységeinek időbeli változását kifejező egységek pedig időszakok).

Ahhoz, hogy egy jelenség átlagos változását meg tudjuk határozni, ismerni kell azt, hogy egy jelenség időbeli alakulását általában le lehet írni valamely tartósan érvényesülő tendenciával. Ez a tartósan érvényesülő tendencia az idősor alapirányzata (trendje). 
Az idősor elemzésekor egy olyan speciális sztochasztikus folyamatot elemzünk, ahol egy véges számú sorozatról van szó. Ha egy folyamat időbeliségét akarjuk elemezni, minden esetben csak egy-egy tapasztalati adat áll rendelkezésünkre (tapasztalati idősor), ahhoz azonban, hogy általánosítani lehessen a tendenciákat meg kell határozni az elméleti idősort. Az elméleti idősornak három összetevője van: az alapirányzat vagy trend, a periodikus ingadozás, illetve a véletlen ingadozás.

Az alapirányzat vagy trend az idősorban tartósan érvényesülő tendencia, amely maga is több tényező együttes hatását tükrözi, attól függően, hogy milyen jelenséget ír le (jele: $\stackrel{\Lambda}{y}$ ).

A periodikus ingadozás az idősorban bizonyos okból fellépő, rendszeresen ismétlődő hullámzás. Ezek közül a leggyakoribb az idényszerủ vagy szezonális ingadozás. A szezonális ingadozás állandó periódus-hosszúságú hullámzás (jele: S).

A véletlen ingadozás az egyenként nem jelentős, egymás hatását elösegítő vagy gátló tényezők végső eredményei, amelyek a véletlen hatásának tudhatók be (jele: v).

A három komponens között kétféle kapcsolat létezhet, melyek az additív és multiplikatív kapcsolatok lehetnek. Az additív mód azt jelenti, hogy a három összetevő a lehető legegyszerübb módon kapcsolódnak, a komponensek összege adja a t-edik időszakban ténylegesen megfigyelt értéket $\left(y_{t}=\hat{y}_{t}+s_{t}+v_{t}\right)$.

A multiplikatív mód esetében a három összetevő szorzat adja meg a t-edik időszakban ténylegesen megfigyelt értéket $\left(y_{t}=\hat{y}_{t} \cdot s_{t}^{*} \cdot v_{t}^{*}\right.$, ahol a $*$ jel a multiplikatív módon kapcsolódó komponenset jelzi).

Ahhoz, hogy el tudjuk dönteni, hogy az idősor összetevői esetén additív vagy multiplikatív számítást kell-e végezni grafikont kell készíteni. A pontdiagramon azt nézzük meg, hogy a periodikus ingadozás hullámai milyen jellegüek. Ha növekvő vagy csökkenő trend mellett nagyjából egyenlő amplitúdójúak a hullámon, akkor additív a kapcsolat. Ha időben növekvő vagy csökkenő tendenciát mutat a periodikus ingadozás hulláma, akkor multiplikatív a kapcsolódás.

Cikkem egy részében a trend számításánál a mozgóátlagok módszerét alkalmaztam. A mozgó átlagolás esetén a trendet az eredeti adatsor dinamikus átlagaként állíthatjuk elő (Portfolio, 2019). A gyakorlatban igen elterjedt trendszámítási módszer, mert egyszerü és gyorsan számítható. Hátránya viszont, hogy a kiegyenlített sor rövidebb, kevesebb adatot tartalmaz, mint az eredeti, agy nagyon rövid idősor esetében szinte lehetetlen a trendet ezen módszerrel egyértelmüen. A számítás alapja, hogy el kell dönteni a tagszámot (mennyi elemet átlagoljuk). A mozgó átlagolású trendszámítás kiküszöböli a két másik (periodikus ingadozás, véletlen) tényező hatását, és kiegyenlíti az idősort.

A számítások másik részénél az analitikus trendszámítást alkalmaztam. Az analitikus trendszámítás az analitikus regresszió függvény egy speciális esete (Murray, 1995), . A két mennyiségi változó az idő, mint az időintervallumhoz rendelt sorszám, valamint egy időben lejátszódó folyamat ismert adatai (esetemben az 1 MWh-ra ára a kereskedésben). A trendszámítás lényege, hogy az időben lezajló folyamatot valamely matematikai függvény segítségével modellezhessük. 
Az analitikus trendszámítás célja Hunyadi-Vita szerint (2005, 2008), hogy a „t” időegységnek megfelelő sorszám függvényében egy matematikai függvényt kiválasztva meg kell határozni a függvény paramétereit, amely függvény az időben lezajló esemény alaptendenciáját tükrözi (a periodikus ingadozás és a véletlen hatás kiszürésével).

A lineáris trendfüggvény becsült értékeit az $\hat{y}_{t}=b_{0}+b_{1} t$ egyenlet adja meg.

Az egyenletben $a b_{1}$ a függvény meredeksége, mely a trendfüggvény várható értékére megadja az időszakonkénti állandó abszolút változás nagyságát (vagyis a „„" időegységnyi változására mennyivel változik a trend értéke). A $\mathrm{b}_{0}$ a $\mathrm{t}=0$ időponthoz tartozó trendértéket adja meg.

A trend egyenesének a meghatározását követően kerülhet sor a periodikus hullámzások vizsgálatára. Ennek célja, hogy becslésszerủen meghatározzuk az egyes szezonokra vonatkozó hatásokat. Miután az idősorok három komponense additív illetve multiplikatív módon kapcsolódhat egymáshoz, a periodikus hullámzás vizsgálatának is két egymástól eltérő módszere van: additív modell esetén szezonális eltéréseket, míg multiplikatív modell esetén szezonális indexeket kell számolni.

A szezonalítás elemzésének egyik esete az, amikor a trend, a szezonális hatás és a véletlen hatás között additív összefüggés áll fenn. Ez a t-edik időpontra a következő: $y_{t}=\hat{y}_{t}+s_{t}+v_{t}$

A szezonális hatás kimutatásához az idősorban szereplő összes értéket tekintve vonjuk ki a trend értékét, azaz $y_{i, j}-\hat{y}_{i, j}=s_{j}+v_{i, j}$. Ez azt jelenti, hogy ezek az eltérések a szezonalítás mellett még a véletlen hatást is tartalmazzák. Ennek kiküszöböléséhez egy-egy szezonra átlagoljunk, így megkapjuk a j-edik szezonra a szezonális eltérés nyers becslését:

$$
s_{j}^{\prime}=\frac{\sum_{i=1}^{k}\left(y_{i, j}-\hat{y}_{i, j}\right)}{k}=\frac{\sum_{i=1}^{k}\left(s_{j}+v_{i, j}\right)}{k}=s_{j}+\frac{\sum_{i=1}^{k} v_{i, j}}{k} \approx s_{j},
$$

ahol s' a nyers szezoneltérés, míg a „k” értéke az idősorban szereplő periódusok száma.

Ha mozgó átlagolású trend értékekkel számoltunk, akkor szükséges egy korrekció is. Ebben az esetben a nyers szezoneltérésekböl ( $\left.\mathrm{s}_{\mathrm{j}}{ }^{\prime}\right)$ számtani átlagot kell számolni. Ha az értékünk nullánál nagyobb, akkor megkaptuk a véletlen hatását (esetenként ez még korrigálni kell). A szezoneltérés így azt fogja jelenteni, hogy a jedik szezonban a szezonális hatás mennyivel téríti el az idősor értékétől a trendhez képest (negatív előjel esetén csökkenő hatás, pozitív előjelnél növelő hatás).

\section{Eredmények és értékelésük - A magyarországi villamosenergia előállítás, fogyasztás és felhasználás alakulása az elmúlt 30 évben}

A villamos energia értékesítése előtt célszerünek látom áttekinteni Magyarország villamos energia előállításával és fogyasztásával kapcsolatos tényeket. A fogyasztás elemzése érdekében 1990-től napjainkig vizsgáltam meg a rendelkezésre álló 
adatbázisokat. Az elemzésekhez statisztikai mutatókat alkalmaztam, melyeket a Módszer részben mutattam be.

Magyarország villamos energia fogyasztásánál egy lineárisan növekvő pozitív irányú tendenciát tapasztaltam (1. ábra), mivel a rendelkezésre álló adatokra egy lineáris trendet tudtam illeszteni. A pontok alapján a növekvő egyenes egyenlete a következő:

$$
\stackrel{\Delta}{y}=0,3739 x+31,02
$$

ahol a 0,3739 az egyenes meredekségét ( 1 év alatt megközelítőleg 0,37 TWh-val nő a magyarországi lakosság energiafogyasztása), míg a 31,02 a tengelymetszet értékét jelenti a „0”. időszakban. A „0”. időszak értéke az 1989. évet jelenti esetemben. A növekedés a sok elektromos eszköz müködtetésének, a különböző hütő-fütő berendezések alkalmazásának, illetve a technológiák fejlődésének köszönhető. A lineáris trend által meghatározott egyenlet alapján meghatározható a 2019. évre egy elöre jelzett érték. Ez alapján 2019. évre megközelítőleg 42,24 TWh energiafogyasztás várható hazánkban.

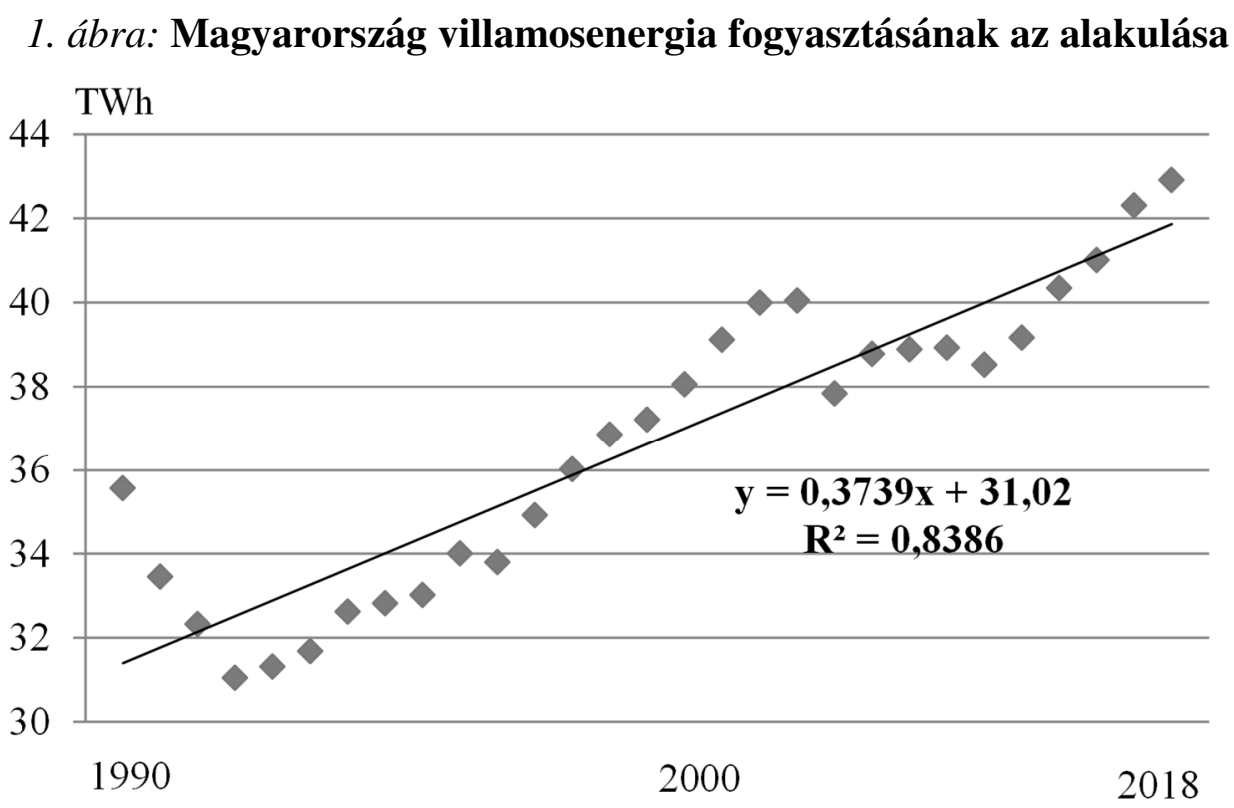

Forrás: Saját kalkuláció az IEA (2019a, 2019b) adatbázisai alapján

A teljes fogyasztás ismerete mellett pontosabb információt kapunk az 1 főre jutó villamos energia fogyasztás ismeretében. Itt is a rendszerváltástól tekintettem át az adatbázist. A számítások alapján az egy főre jutó villamosenergia fogyasztása 3,6 MWh. A kezdeti 3 MWh/fö mennyiségről 30 év alatt megközelítőleg 4,23 MWh-ra növekedett meg az egy före jutó villamosenergia fogyasztás, ami évente átlagosan 0,75\%-os növekedést jelentett (számításokhoz a mértani átlag módszerét alkalmaztam). 
A villamosenergia termelés arányát vizsgálva megállapítható, hogy legnagyobb részaránnyal a nukleáris energia rendelkezett a 2017. évben (2. ábra), majd ezt követték a gáz és a szén részesedései. Látható, hogy Magyarországon jelenleg még nagy alacsony a megújuló energiák részaránya a teljes villamosenergia előállításban. Azonban az Európai Unió 2020-ra előirányzott direktíváinak a megfeleléséhez növelni célszerủ a megújulók részarányát. Tekintve, hogy Magyarország már 2017. évben elérte az EU-ban a vállalt minimális megújuló energia részarányt, így a fó cél ezen érték stabilitása, illetve az üvegházhatású gázok kibocsátásának csökkentése érdekében a megújuló energiaforrások energiagazdálkodásba való minél nagyobb mértékü bevonása. Jelenleg Magyarországon még kihasználatlan kapacitások vannak a megújuló energiák tekintetében. A környezettudatosabb energiagazdálkodás érdekében tehát növelni célszerü a megújulók részarányát.

\section{2. ábra: A villamosenergia-termelés aránya üzemanyaggal Magyarországon} 2017. évben

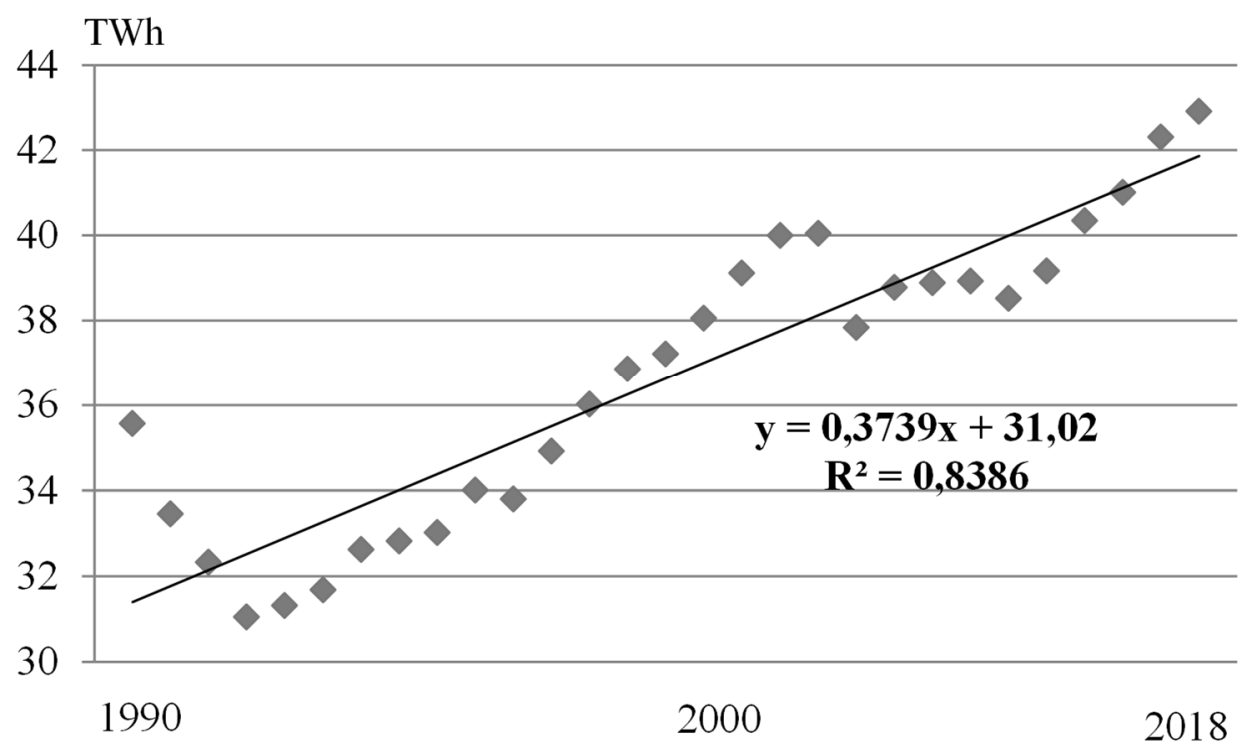

Forrás: Saját kalkuláció az IEA (2019a, 2019b) adatbázisai alapján

A megújuló energiaforrások jelentősége az elmúlt 10 évben kezdett csak növekedni a vizsgált adatok alapján. A 2008. bázis évben még megközelítőleg 400 GWh mennyiséget termeltek megújulók valamelyikéböl, addig 2018-ra ez az érték 3,5-szeresére növekedett meg (3. ábra). 


\section{3. ábra: A villamosenergia-termelés megújuló energiaforrásokból források szerint}

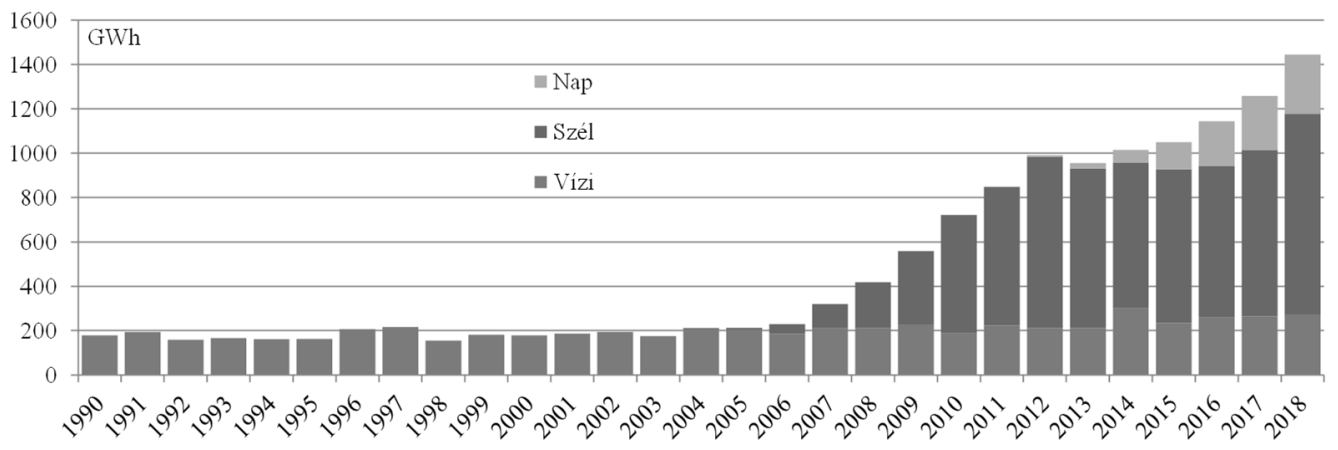

Forrás: Saját kalkuláció az IEA (2019a, 2019b) adatbázisai alapján

1990-től 2000-ig szinte csak a vízenergia adta lehetőségeket használta ki Magyarország. 2000-tôl minimális, de 2006-tól már relatíve nagyobb mennyiségbe vontuk be a szél energiát villamos energia előállítására. 2008-tól minimálisa, 2013tól már érzékelhető mennyiséggel szerepel az energia előállításában a nap energiája is.

A megújuló energiaforrások energiagazdálkodásba való bevonása fontos szempont az Európai Unió tagországai számára. 2020-ra vonatkozóan minden tagország esetében el kell elérni a korábban bevállalt százalékos értéket, mely Magyarország számára ez megközelítőleg $15 \%$-ot jelent a teljes villamosenergia termelésen beül. A 4. ábrán jól látható, hogy minden - Magyarország számára fontos - megújuló energiaforrás esetében növekedés következett be.

\section{4. ábra: A megújuló energiaforrásokból való villamos energia előállításnak az alakulása Magyarországon 1990-től napjainkig}

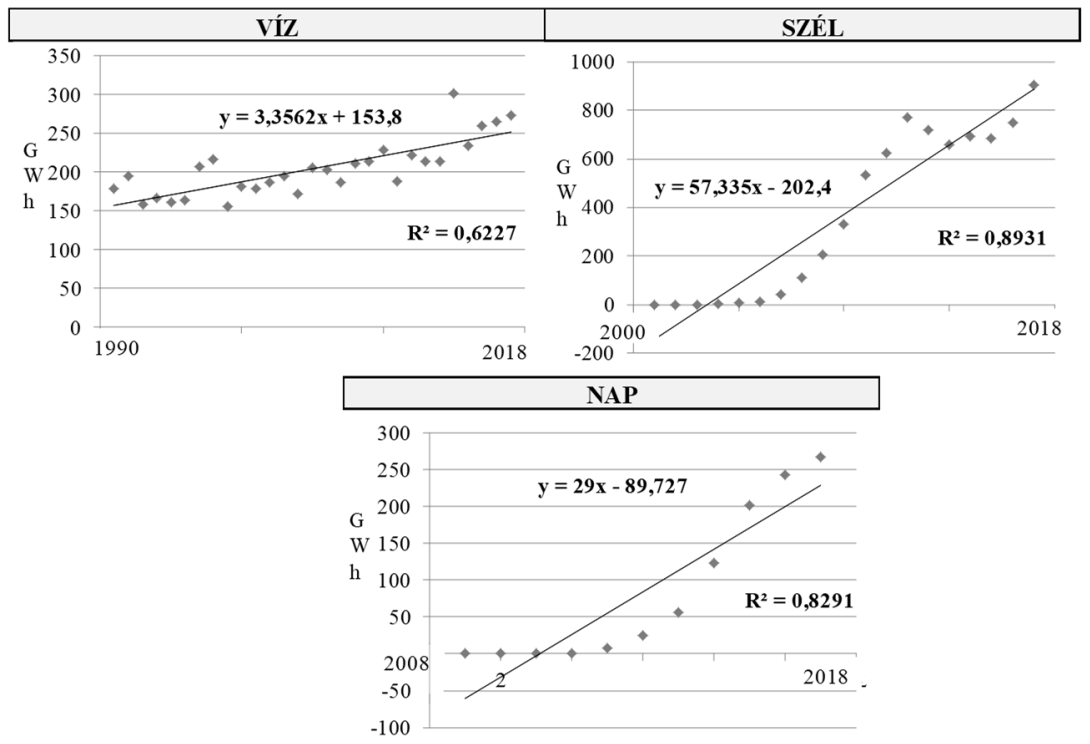

Forrás: Saját kalkuláció az IEA (2019a, 2019b) adatbázisai alapján 
Az általam elkészített kalkulációk alapján a víz esetében 3,36 GWh, a szél esetében 55,33 GWh, míg a nap esetében $29 \mathrm{GWh}$ emelkedés figyelhető meg évente a vizsgált időszakban. A víz esetében 1990-től, a szélnél 2000-től, míg a nap esetében 2008-tól vizsgáltuk a tendenciákat, mivel korábban nem volt villamosenergia termelés belőlük nagyobb mértékben. A kalkulációim alapján a 2019. évre vonatkozóan elörejelzést készítettem az elmúlt majdnem 30 év adata alapján, ahol megállapítottam, hogy elöreláthatólag 344 GWh víz, 940 GWh szél és 282 GWh napenergia kerül előállításra.

A magyarországi villamosenergia fogyasztás és előállítás áttekintését követően a villamosenergia értékesítését kívánom bemutatni.

\section{Eredmények a villamos energia értékesítéséről a HUPX ZRt.-nél}

Az Európai Unió egyes tagországai számára fontos, hogy a villamos energia piacon a szomszédos, illetve a részben szomszédos országokkal árukereskedelmet bonyolítson le a jobb árszabályozás érdekében.

A cikkemben a HUPX ZRt. villamos energia tőzsdei árukereskedését vizsgálom meg a kezdetektől (müködéstől) egészen napjainkig Magyarországon.

Abban az esetben, ha az egy napon belüli értékesítéseket vizsgáljuk meg, akkor az adott napon belül intervallumokat lehet elkülöníteni az értékesítési árak alapján. A vizsgálathoz az elmúlt 1 év (2018.03.01. - 2019.02.28) minden napjának minden órájában mért adatait vizsgáltam meg a HUPX ZRt. EURÓ/1 MWh adataira vonatkozóan. Az adatok alapján az értékesítés szempontjából a leggyengébbnek a nap első 6 órája tekinthető, mivel ekkor 1 MWh mennyiséget 34-43 euró közötti áron lehet átlagosan értékesíteni. Ezzel szemben a 1700-2100 óra között a legmagasabb az értékesítési ár, mivel 5\%-os véletlen hatást feltételezve 64-74 euró között tudtak 1 MWh-ot értékesíteni (5. ábra).

\section{5. ábra: A villamos energia értékesítésének az alakulása 1 MWh-ra vetítve euróban kifejezve 2018.03.20 -2019.03.20 közötti időszakban}

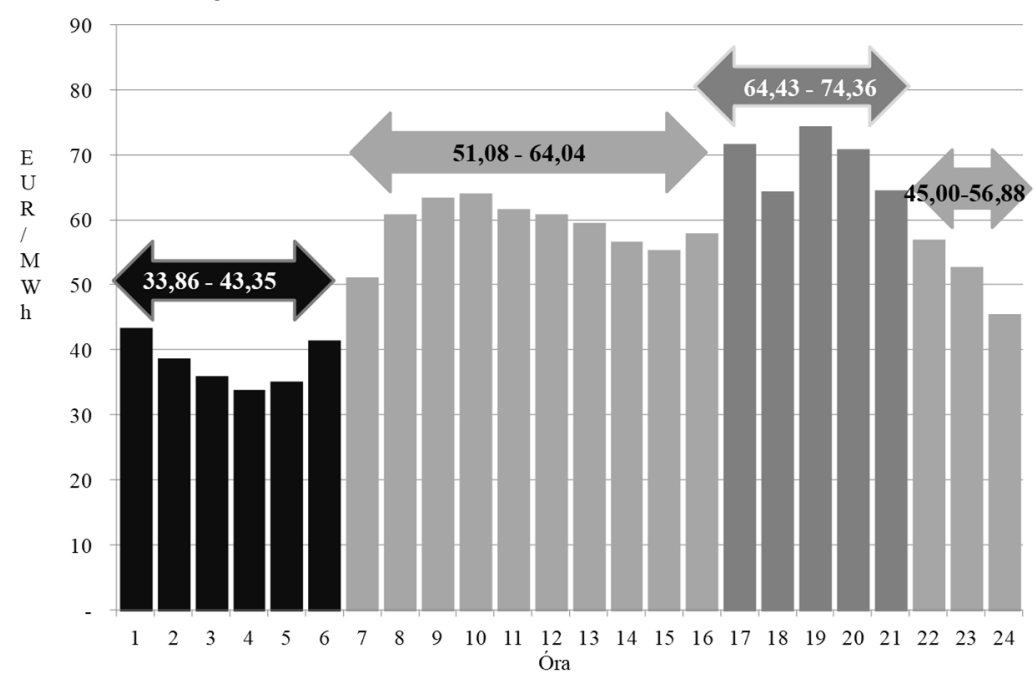

Forrás: Saját kalkuláció a HUPX ZRT. adatbázisa alapján 
A kapott eredmények megbízhatóságát is megvizsgáltam. A 17 órától következő nap 6 óráig 4,0-4,3 euróval, míg 7-től 16 óráig megközelítőleg 7,6 euróval változik az árfolyam.

Az eladási érték mellett természetesen fontos az eladott mennyiségek vizsgálata is. Itt is a 2018.03.20-2019.03.20 közötti időszakot vizsgáltam meg. A 365 nap áttekintését követően arra a megállapítása jutottam, hogy napon belül a legnagyobb mennyiségeket 10-14 óra közötti időszakban adják el. Eladás szempontjából a legkevesebb mennyiség reggel 5 és 7 óra között cserélt gazdát (6. ábra).

\section{6. ábra: A villamos energia értékesítésének átlagos mennyiségi alakulása napon belül a 2018.03.20 -2019.03.20 közötti időszakban}

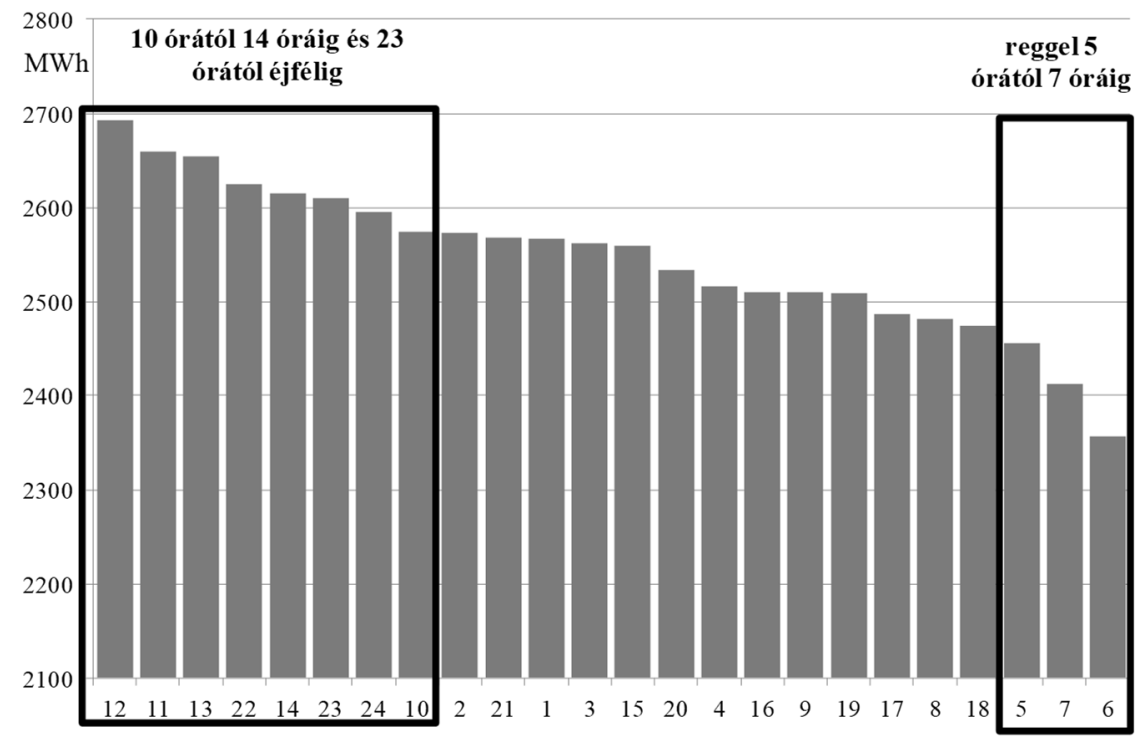

Forrás: Saját kalkuláció a HUPX ZRT. adatbázisa alapján

Az egyes napok vizsgálata esetén megállapítottam, hogy az értékesítés hétvégén (szombattól hétfőig) alacsonyabb, míg hétköznap (keddtől péntekig) magasabb.

7. ábra: A villamos energia értékesítésének átlagos mennyiségei az egyes napokon a 2018.03.20 -2019.03.20 közötti időszakban

$\begin{array}{lllllllll}30500 & 31000 & 31500 & 32000 & 32500 & 33000 & 33500 & 34000 & 34500\end{array}$

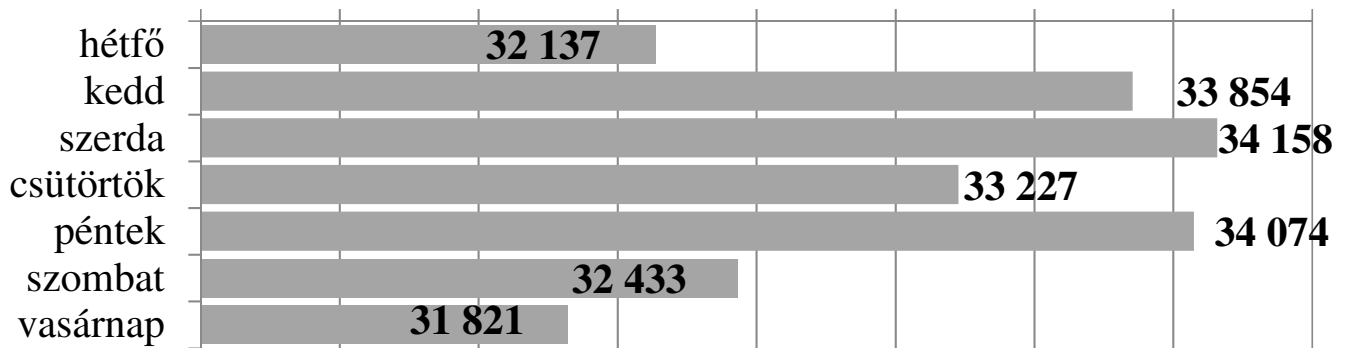

Forrás: Saját kalkuláció a HUPX ZRT. adatbázisa alapján 
Mivel tapasztaltam, hogy az egyes napok között különbség van az értékesítés szempontjából így megvizsgáltam a 2019. év március hónapjának az értékesítési alakulását. Látható, hogy a legjobb vételi és eladási árak között szoros kapcsolat van. 4 olyan nap volt a hónapon belül, amikor a kínálati ár meghaladta a vételi ár értékét. Két kimagasló nap volt a hónapon belül, melyek a 9. és 28. napot érintették, amikor is 7,12 és 9,59 euróval volt magasabb a vételi ár, mint a kínálati ár, mely nagy különbséget jelent az árak között. A 2019. év többi hónapjára is megvizsgáltam ugyanezen összefüggéseket, s minden hónap esetében 2-3 kiugró nap volt, amikor magasabb volt a kínálati ár értéke (8. ábra).

\section{8. ábra: A legjobb kínálati ár és vételi ár közötti összefüggés 2019. év márciusában Magyarországon}

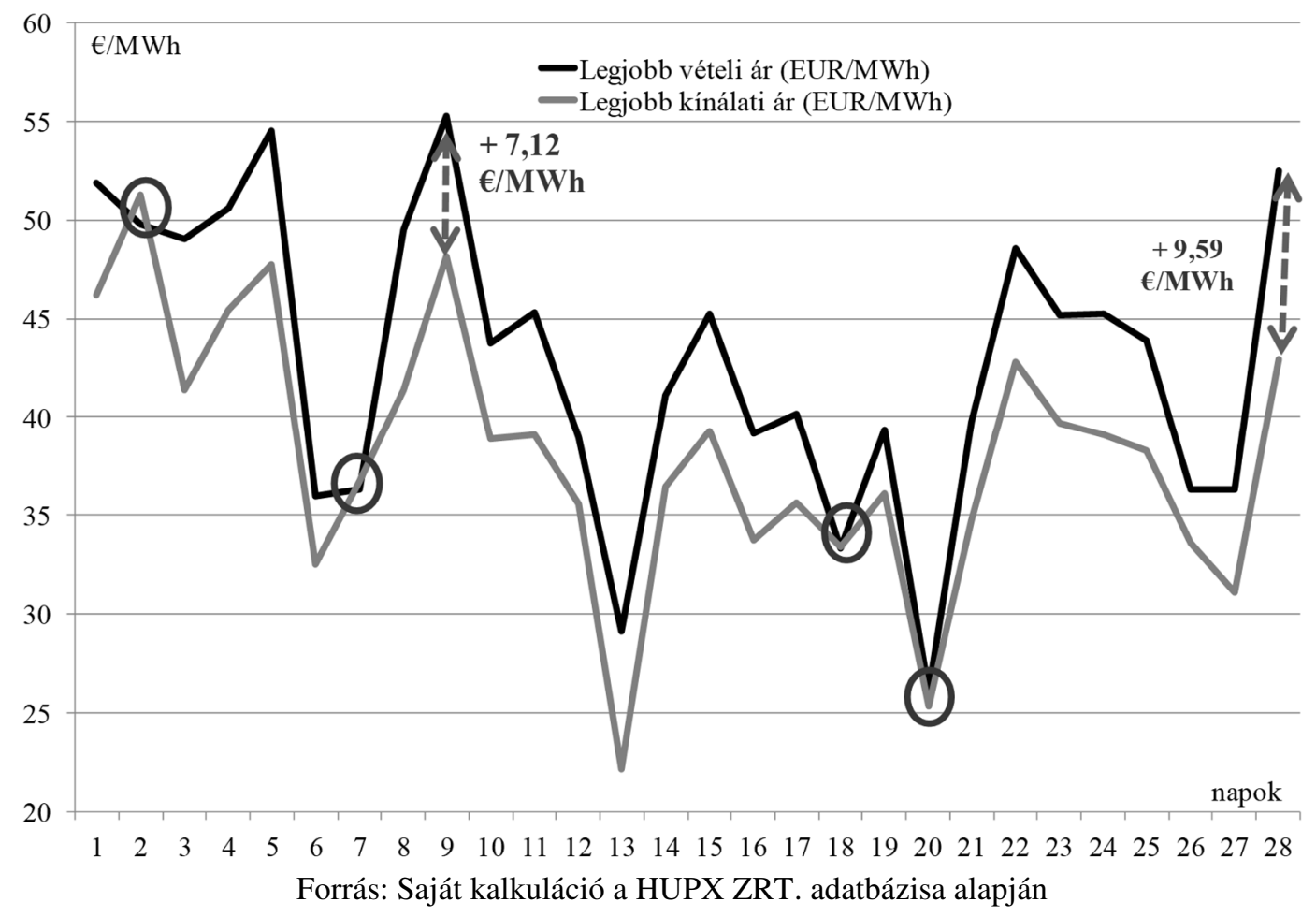

A vételi és kínálati árak vizsgálata esetén megállapítható, hogy az adatok szoros kapcsolatban vannak egymással, mivel a regresszió számítás során megállapításra került, hogy a Pearson féle r érték 0,94, azaz nagyon szoros kapcsolat van a vételi és eladási ár között (9. ábra). A determinációs együttható vizsgálata során megállapítottam, hogy az egyik változó a másik változó értékét 88\%-ban magyarázza (vételi ár magyarázza a későbbi eladási árat), tehát a szorosság itt is bizonyítást nyert. A vizsgált adatokra elkészített regressziós egyenes paramétereiből megállapítható, hogy a vétel esetében, ha egy euró nő a villamos energia ára, akkor eladáskor 0,82 euróval nő a villamos energia már meglévő ára. A kapott eredmények ellenőrzése érdekében a kapott standard maradékok értékeire elkészítettem a normális eloszlást követő hisztogram ábráját is. 
9. ábra: A legjobb kínálati ár és vételi ár közötti összefüggés 2019. év márciusában Magyarországon

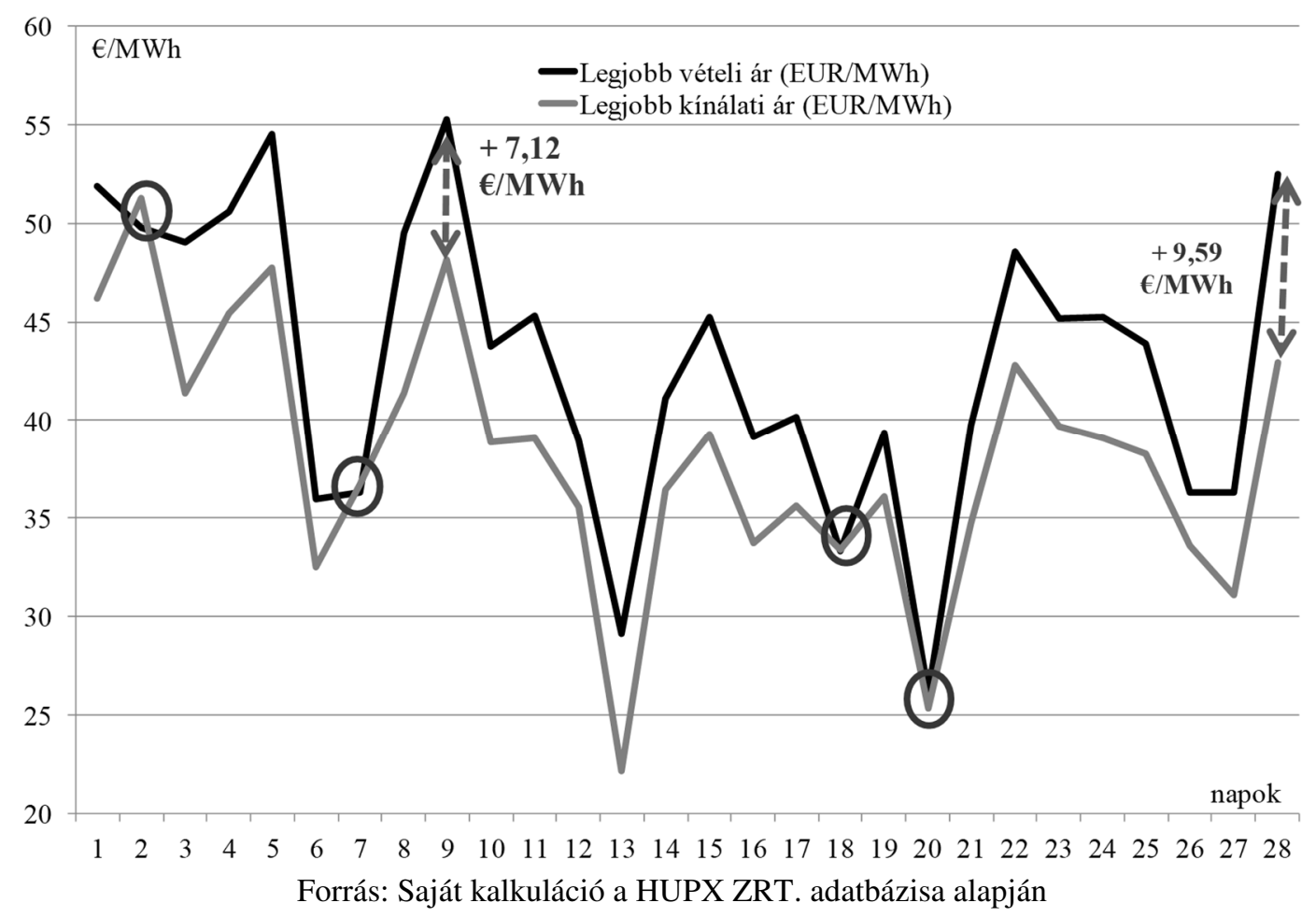

\section{Következtetések, összegzés, záró megjegyzések, záró gondolatok}

A cikkemben a magyarországi villamosenergia piac helyzetét mutattam be rendszerváltástól napjainkig. A szakirodalmi adatok alapján látható, hogy napjainkban a villamosenergia piaccal érdemes foglalkozni, mivel a piacon folyamtatos változások vannak. Mivel az elmúlt 5 évben a magyar villamosenergia piacot a HUPX ZRt. müködteti, így fontosnak láttam áttekinteni az értékesítési napok alakulását mind euróban, mind mennyiségben.

Cikkemben a „HUPX” piac gazdasági jelentőségét mutattam be Magyarországon a HUPX ZRt. müködésétől vezetett adatbázisain keresztül. Külön figyelmet szenteltem a „,napon belüli”, illetve a „másnapi piacok vizsgálatára” is. A számításaimhoz a MAVIR ZRt. által irányított magyar közcélú hálózaton leszállított villamos energiát vizsgáltam figyelembe véve a villamosenergia-rendszer Üzemi Szabályzatának rendelkezéseit.

\section{Irodalomjegyzék}

Hunyadi L., Vita L. (2005): Statisztika közgazdászoknak. ISBN: 9632157427 . Akadémiai Nyomda. Központi Statisztikai Hivatal. Budapest. 770. p.

Hunyadi L., Vita L. (2008): Statisztika I. és II. Aula. ISBN: 9789639698239. Budapest HUPX (2019a): <https://hupx.hu/hu/piaci-adatok/dam/historikus-adatok> (2019.03.17) HUPX (2019b): <https://hupx.hu/hu/rolunk/ceginformacio> (2019.03.10) 
IEA (2019a): <https://www.iea.org/statistics/?country=HUNGARY\&year=2016\&category=Energy \%20supply\&indicator=TPESbySource \&mode $=$ chart\&dataTable $=$ BALANCES $>$ (2019.03.07)

IEA (2019b): <https://www.iea.org/statistics/?country=ROMANIA\&year=2016\&category=Energy $\%$ 20supply\&indicator=OilProd $\&$ mode $=$ chart $\&$ dataTable $=$ OIL $>(2019.02 .01)$

MAVIR (2019): <https://www.mavir.hu/web/mavir/import-export> (2019.03.10)

Murray R. Spiegel (1995): Statisztika. Elmélet és gyakorlat. Panem - McGrraww - Hill. 546 p.

Portfolio (2019): <https://www.portfolio.hu/vallalatok/technikai-elemzes/technikai-elemzes-amozgoatlag-hasznalata.17774.html> (2019.03.18) 